IZA DP No. 9292

Health Insurance Benefit Mandates and the Firm-Size Distribution

James Bailey

Douglas Webber

August 2015 


\title{
Health Insurance Benefit Mandates and the Firm-Size Distribution
}

\author{
James Bailey \\ Creighton University \\ Douglas Webber \\ Temple University and IZA \\ Discussion Paper No. 9292 \\ August 2015 \\ IZA \\ P.O. Box 7240 \\ 53072 Bonn \\ Germany \\ Phone: +49-228-3894-0 \\ Fax: +49-228-3894-180 \\ E-mail: iza@iza.org
}

\begin{abstract}
Any opinions expressed here are those of the author(s) and not those of IZA. Research published in this series may include views on policy, but the institute itself takes no institutional policy positions. The IZA research network is committed to the IZA Guiding Principles of Research Integrity.

The Institute for the Study of Labor (IZA) in Bonn is a local and virtual international research center and a place of communication between science, politics and business. IZA is an independent nonprofit organization supported by Deutsche Post Foundation. The center is associated with the University of Bonn and offers a stimulating research environment through its international network, workshops and conferences, data service, project support, research visits and doctoral program. IZA engages in (i) original and internationally competitive research in all fields of labor economics, (ii) development of policy concepts, and (iii) dissemination of research results and concepts to the interested public.
\end{abstract}

IZA Discussion Papers often represent preliminary work and are circulated to encourage discussion. Citation of such a paper should account for its provisional character. A revised version may be available directly from the author. 
IZA Discussion Paper No. 9292

August 2015

\section{ABSTRACT \\ Health Insurance Benefit Mandates and the Firm-Size Distribution}

By 2010, the average US state had passed 37 health insurance benefit mandates (laws requiring health insurance plans to cover certain additional services). Previous work has shown that these mandates likely increase health insurance premiums, which in turn could make it more costly for firms to compensate employees. Using 1996-2010 data from the Quarterly Census of Employment and Wages and a novel instrumental variables strategy, we show that there is limited evidence that mandates reduce employment. However, we find that mandates lead to a distortion in firm size, benefiting larger firms that are able to self-insure and thus exempt themselves from these state-level health insurance regulations. This distortion in firm size away from small businesses may lead to substantial decreases in productivity and economic growth.

JEL Classification: L51, I13, I18, J32

Keywords: health insurance, benefit mandates, self-insurance, interest groups, employment, firm size

Corresponding author:

Douglas A. Webber

Department of Economics

Temple University

1301 Cecil B. Moore Ave

Ritter Annex 883

Philadelphia, PA 19102

USA

E-mail: douglas.webber@temple.edu 


\section{Introduction}

US states have passed a large and rapidly increasing number of health insurance benefit mandates. Benefit mandates require health insurance plans to cover a specific treatment, condition, provider, or type of person (such as acupuncture, autism, chiropractor visits, or grandchildren of a planholder). These additional benefits are likely to increase health insurance premiums (Bailey 2013; Kowalski, Congdon, and Showalter 2008). Rising health insurance premiums increase labor costs for employers who provide health insurance to their employees. Those increased costs could lead employers to reduce health insurance coverage, wages, or employment. Alternatively, firms can legally escape mandates by self-insuring if they are willing to bear the risk of paying employees' health insurance claims. Large firms can more easily take advantage of this loophole. Hence, the passage of health insurance benefit mandates may give these firms a competitive advantage. In this paper, we use a novel empirical strategy to determine the extent to which health insurance benefit mandates affect employment and firm size in the United States.

We make four new contributions in this paper. First, we examine the effect of health insurance mandates, in general, on employment using recent data. Previous work examined the effects of a single mandate (Bailey 2014; Gruber 1994a; Lahey 2012; Wolaver, McBride, and Wolfe 2003) or a handful of specific mandates (Meer and West 2011) or examined the effect of mandates only for the 1990s (Kaestner and Simon 2002; Mathur 2010).

Second, we are the first to show empirically that health insurance mandates can distort firm size. Large firms are more easily able to self-insure and avoid state-level health insurance mandates, leaving small firms with relatively higher costs. 
Third, our identification strategy takes into account the political forces behind the passage of mandates, rather than assuming mandates are passed at random as other researchers have done. We overcome the endogeneity problem by using novel instruments, that is, the political variables that have been determined affect the passage of mandates. ${ }^{1}$

Fourth, we use a dataset novel to the literature on health insurance benefit mandates, the Quarterly Census of Employment and Wages (QCEW). These administrative data from the US Bureau of Labor Statistics ${ }^{2}$ have provided employment by firm size and state for almost all firms in the United States since 1990. Meer and West (2011) argue convincingly that most previous work on the labor market effects of mandates suffers from severe attenuation because of reliance on datasets with high sampling error. The QCEW avoids this sampling error by using administrative data from the full population of firms rather than self-reported data from a sample of firms.

We find that mandates do not lead to statistically significant decreases in employment but do distort the distribution of firm size by increasing the number of very large firms (greater than 1,000 workers) and reducing the number of small firms. Such a distortion may have a negative effect on aggregate productivity and job growth (Haltiwanger, Jarmin, and Miranda 2013).

\footnotetext{
${ }^{1}$ In an earlier study, Webber and Bailey (2014) found that states with more doctors per capita passed more mandates, and states with greater political contributions by health insurers passed fewer. In this study, we therefore use doctors per capita and political contributions by insurers as our two instruments for the number of mandates in each state. The 2014 study also found that other variables that might be expected to affect the passage of mandates, such as the political party of the governor and state legislature or the proportion of individuals with private health insurance, were in fact insignificant.

${ }^{2}$ The QCEW is publicly available on the Bureau of Labor Statistics website: http://www.bls.gov/cew/home.htm
} 


\section{Previous Work: Theory and Evidence on the Effects of Mandates}

\subsection{The Summers Model and the Effects of Health Insurance Benefit Mandates on}

\section{Employment}

In 1989, Lawrence Summers proposed a simple model of how mandated benefits should affect the labor market. In the Summers model, a mandated benefit decreases labor demand as if it were a tax equal to the cost of the benefit. Unlike a tax, the mandate also increases labor supply by an amount equal to the value workers receive from the benefit. For example, suppose that a mandated benefit costs employers $\$ 1,000$ to provide. If workers value the benefit fully at cost $(\$ 1,000)$, then the number of hours worked in equilibrium is unchanged; employers reduce money wages by $\$ 1,000$ dollars, but employees perceive that the total value of their compensation is unchanged. If workers receive no value from the benefit, then they perceive that the total value of their compensation has decreased by $\$ 1,000$, leading to a reduction in equilibrium hours worked; the effect is equivalent to a $\$ 1,000$ per worker tax. If workers value the benefit at some fraction of its cost, say $\$ 600$, then they perceive a $\$ 400$ reduction in the value of their compensation and would reduce hours accordingly.

Summers intended for his model to apply to a range of mandated benefits, from workers' compensation to health insurance benefit mandates. But an important complication arises when applying the Summers model to health insurance benefit mandates - namely, that health insurance is a lump-sum benefit. Working one more hour at the margin rarely leads to a marginal increase in health insurance coverage. This difference led Feldman (1993) to propose his own model, in which mandating generous health insurance coverage leads each employee to work more hours to bring their total monetary compensation back up, restoring the balance of nonhealth consumption with health insurance. In the Feldman model, the effect of health insurance 
mandates is to increase hours worked among the employed while decreasing the total number of employees. Cutler and Madrian (1998) make a similar argument that increases in health insurance premiums (whatever the cause) increase fixed costs per worker and so will lead to an increase in hours worked per employee but a decrease in the number of employees. Whereas the Summers model differs from the two later models on how mandates should affect hours worked, all three models describe mechanisms by which mandates could reduce employment.

\subsection{Practical Considerations of the Effects of Mandates on Employment}

Why should we expect health insurance benefit mandates to affect employment in the first place? After all, health insurance benefit mandates are aimed at health insurers, not employers. Several conditions must be met for health insurance benefit mandates to be binding on employers. First, the law must actually apply to the health insurance plan. Self-insured health insurance plans, commonly used by large firms, are exempt from state-level health insurance regulations by the federal Employee Retirement Income Security Act (ERISA) of 1974.

Second, the mandate must increase the costs of insurers enough to be reflected in increased premiums. The empirical literature has found mixed evidence of this for individual health insurance: LaPierre and others (2009) found that mandates do not increase premiums; Kowalski, Congdon, and Showalter (2008) found that they do; Gohmann and McCrickard (2009) found that some mandates raise premiums while others do not. Most relevant for our analysis, the only researcher to analyze the effect of mandates on employer-based plans (rather than individual plans) found that the average mandate does significantly increase employer premiums by $0.44 \%-1.11 \%$ (Bailey 2013 ).

Finally, for mandates to affect employers in the sense described in the Summers model, they must offer health insurance in the first place. This is generally a reasonable assumption. 
According to Medical Expenditure Panel Survey data summarized by the Kaiser Family Foundation $^{3}$, in $2012,50 \%$ of private sector establishments offered health insurance to their employees. However, firm size makes an important difference in the likelihood of employees being offered health insurance: according the same data, 35\% of establishments with fewer than 50 employees offer health insurance and $96 \%$ of those with 50 or more employees do.

Though not all employers offer health insurance, and loopholes and cost-sharing dissipate some of the cost of mandates on employers, it still seems reasonable to expect that mandates could cause disemployment at some firms. Cutler and Madrian $(1998, \mathrm{p} 509)$ went so far as to say that "increases in the cost of providing health insurance must have some effect on labor markets, either in lower wages, changes in the composition of employment, or both." We expect this effect to be largest on medium-sized firms, who are most likely to be purchasing health insurance that is subject to mandates. Most small firms do not offer health insurance in the first place and so experience no direct effect on their labor costs when health insurance premiums increase. The largest firms are usually able to self-insure, ${ }^{4}$ taking direct financial responsibility for their employees' health insurance claims instead of paying a fixed premium. This exempts them from state-level regulations, including mandates.

\subsection{Empirical Work on Various Effects of Health Insurance Benefit Mandates}

Work on the effects of mandates has largely focused on whether mandates decrease the chance that employers offer health insurance and on whether they decrease the number of individuals

\footnotetext{
${ }^{3}$ Available at http://kff.org/state-category/health-coverage-uninsured/private-sector-coverage/

${ }^{4}$ See section 2.5 for further discussion of self-insurance.
} 
with employer-provided health insurance. A few researchers have examined labor market effects of mandates in general on outcomes like wages. ${ }^{5}$

Other researchers have looked for the labor market effects of particular mandates aimed at a specific identifiable group. These studies have tended to find strong effects, presumably because it is easier for employers to substitute from one group of workers to another than to substitute away from workers in general ${ }^{6}$. Gruber (1994a) finds that maternity-care mandates resulted in reduced wages, although not reduced employment, for women of child-bearing age. Lahey (2012) and Bailey (2014) find that group-specific mandates (for infertility treatments and prostate cancer screening, respectively) decreased employment for the groups the mandates were meant to benefit.

\subsection{Empirical Work on the Effect of Mandates on Employment}

To date, three groups of researchers have examined the effects of mandates, in general, on employment. All focused on small firms, ${ }^{7}$ none had an explicit strategy to overcome the endogeneity of mandates, and only one found statistically significant disemployment effects.

Kaestner and Simon (2002) use Blue Cross Blue Shield Association data ${ }^{8}$ on mandates to cover treatments and conditions (though not providers) from 1993, 1997, and 1998, along with data on hours worked, weeks worked, wages, health insurance, and employment from the Current Population Survey (CPS) for March 1989-1998. After running individual-level ordinary

\footnotetext{
${ }^{5}$ Jensen and Gabel (1992) find that mandates do decrease the chance that employers offer health insurance. Gruber (1994b) and Kaestner and Simon (2002) find that mandates do not significantly reduce the number of individuals with employer-provided health insurance, and Sloan and Conover (1998) and van der Goes, Wang, and Wolchik (2011) find that they do. Kaestner and Simon (2002) find some evidence of wage decreases from mandates but conclude those decreases are likely spurious.

${ }^{6}$ Lennon (2015) provides a search-theoretic model in which insurance mandates cause workers with high expected health costs to experience lower earnings, higher unemployment, and longer unemployment spells.

${ }^{7}$ Kaestner and Simon (2002) and Meer and West (2011) study firms with fewer than 100 employees; Mathur (2010) studies firms with fewer than 50 employees, with a special focus on firms with 5 or fewer.

${ }^{8} \mathrm{We}$ use an updated version of these data in this paper. See Laudicina, Gardner and Holland (2011) for a description.
} 
least squares (OLS) regressions with state and year fixed effects, they find that mandates had no statistically significant effect on employment.

Mathur (2010) uses 1993-1995 Blue Cross Blue Shield Association data on mandates and 1993-1995 Survey of Income and Program Participation data on employment in small businesses (1-50 employees). Mathur runs an ordered probit regression with no state fixed effects to determine number of employees in small firms of various sizes and finds that mandates do significantly reduce employment at small firms.

Meer and West (2011) investigate the effect of nine high-cost mandates on employment in small firms (0-20 and 20-99 employees). They use 1989-2008 Statistics of US Business (SUSB) data on employment, which is a US Census Bureau product closely related to the Quarterly Census of Employment and Wages that we use in our study. Using fixed effects estimation of state-year-level data, they find that most of their nine mandates do not reduce employment; however, they find some evidence that mandates for drug abuse and mental health treatment do.

Meer and West (2011) argue that previous researchers had been unable to identify an effect of mandates on small business employment because they used smaller datasets such as the CPS data that suffer from sampling bias. While the CPS seems large, with about 170,000 observations annually, it does not have many employees of small businesses in any given stateyear bin. Meer and West show that state-year estimates of small business employment are incredibly noisy in the CPS compared to datasets such as the SUSB that capture the full population of employer firms (about 7 million annually) rather than a small sample of employees. SUSB data show that small business employment in a state essentially never changes 
by more than $10 \%$ from one year to the next, while CPS data show this happening in $38 \%$ of all state-year observations.

Bhattacharya and Vogt (2000), like Meer and West (2011), show how previous work using the CPS had little chance of detecting the true effect of mandates on employment. They calculate that Gruber (1994a) and Kaestner and Simon (2002) use CPS data that did not have the statistical power available to detect the effects the researchers were testing for. Although these papers found no statistically significant disemployment effects of mandates, their $95 \%$ confidence intervals include employment decreases of at least $2 \%$.

\subsection{The Effect of Mandates on Firm Size and Self-Insurance}

To our knowledge, ours is the first paper to investigate the effect of health insurance benefit mandates on firm size. A range of previous work has studied various other regulations that target businesses above or below a certain threshold number of employees. Kapur and others (2012) found that nonmandate US health reforms that explicitly targeted small-group insurance, such as guaranteed-issue laws, led to a decrease in the number of small firms. Garicano, Lelarge, and Van Reenen (2012) examine a French labor law that increases firing costs for firms with 50 or more workers. They find that the law led to a distortion in firm size, which in turn decreased overall productivity.

We expect mandates to lead to a distortion in firm size primarily because of ERISA. This federal law allows firms that self-insure to be exempt from many state-level health insurance regulations, including health insurance benefit mandates. Self-insuring means directly bearing financial responsibility for employees' health insurance claims rather than paying predictable premiums to a separate health insurer who pays the claims as they arrive. Self-insured firms may still hire third-party administrators to process claims. According to Fronstin (2012), 57.5\% of 
those with employer-sponsored health insurance were covered by self-insured plans in 2010, up from 46\% in 1996 (when the data used in our paper begin).

Health insurance claims are variable, which creates risk for those paying them. That is why so many individuals and firms buy insurance in the first place; they want someone else to cover the risk. Insurers, by pooling many individuals with near-uncorrelated risks, can face a relatively smooth stream of claim payments. This logic of insurance means that larger firms will find it easier to self-insure. The more workers they can pool, the lower the chance that a large proportion of them will become catastrophically ill in the same year. This logic is borne out clearly in the data. According to 2010 Medical Expenditure Panel Survey data summarized by Fronstin (2012), firms with fewer than 50 employees have only $12.5 \%$ of covered workers in self-insured plans compared to $37.6 \%$ for firms with 100-999 employees and $83.6 \%$ for firms with 1,000 or more employees.

Because self-insured firms are exempt from mandates and large firms are much more likely to self-insure, we expect mandates to prove costly for smaller firms while providing a relative advantage for large firms (especially those with 1,000 or more employees).

\subsection{Our Contribution to Understanding the Effects of Mandates on Employment}

Our main contribution to research on the effect of health insurance mandates is to use novel instrumental variables for mandates, taking into account that mandates are the outcome of a political process and are not passed randomly as natural experiments. The only step toward addressing the endogeneity problem in previous work was the use of state fixed effects by Kaestner and Simon (2002) and Meer and West (2011).

In addition, like Meer and West but unlike other previous researchers, we use an employment dataset that draws from Internal Revenue Service payroll data to capture nearly the 
full population of firms and workers rather than relying on survey data that contacts only a small sample of workers. Our new identification strategy allows us to more cleanly identify the effect of mandates on employment and firm size. Finally, we are the first to estimate the extent to which mandates distort firm size.

\section{Data and Empirical Strategy}

\subsection{Health Insurance Benefit Mandates}

Health insurance benefit mandates are laws commonly passed by states that specify what insurers must cover. They may require insurers to cover specific treatments or procedures (for instance, rehabilitation for alcoholism) or to cover certain types of providers (such as midwives or acupuncturists). Less commonly, they may require insurers to offer coverage to certain sorts of people (for instance, adult dependent children in a family plan).

We use data on the number of mandates in force in each state from 1996 to 2010 , compiled by the Blue Cross Blue Shield Association and presented by Laudicina, Gardner, and Holland (2011). This data on mandates has often been used in academic research, for example by Kaestner and Simon (2002) and by Webber and Bailey (2014). The data, summarized in table 1, reveal a great deal of variation among states, as well as the general trend of an increase in the number of mandates over time. The average state had 20 separate benefit mandates in 1996, increasing to 36 by the end of our sample in 2010 .

\subsection{Employment and Establishment Size}

Our data on employment come from the QCEW. This administrative dataset, compiled by the US Bureau of Labor Statistics using reports from all establishments that report to unemployment insurance programs, reaches essentially all businesses in the United States (approximately 97\%). 
Bhattacharya and Vogt (2000) argue that survey datasets such as the CPS do not have the statistical power to determine the effect of mandates on employment; Meer and West (2011) concur and argue that administrative data is superior. These arguments, which we discussed in greater detail in section 2.4, demonstrate why our use of the QCEW is appropriate.

The QCEW provides data broken out by establishment size rather than firm size. An establishment is "typically at one physical location and engaged in one, or predominantly one, type of economic activity for which a single industrial classification may be applied." ${ }^{9}$ A firm may consist of multiple establishments. Whether firm-level data would be more appropriate than establishment level depends on how often multi-establishment firms use the same health insurance across establishments. If firms commonly use the same plan across establishments, especially if that plan is self-insured, then firm-level data would be more appropriate than the establishment-level data we use. However, it appears this is not the case, because small establishments within larger firms are actually less likely to offer health insurance than singleestablishment firms of the same size (Glied, Lambrew, and Little 2003, 22).

We use annual QCEW data on employment by establishment size in each state from 1996 to 2010. The administrative data used to build the QCEW are incredibly rich, containing data on the exact size of almost every firm in the United States. Unfortunately, to protect the privacy of firms, the QCEW provides this data aggregated only up to the state level. The QCEW breaks establishments down into nine size categories, ranging from establishments with fewer than 5 employees to those with more than 1,000 . Thus, we observe the total number of establishments and the number of employees in each size category in each state and year. Table 1 shows summary statistics for the number of establishments and total employment by establishment size.

\footnotetext{
${ }^{9}$ Quote is from the US Bureau of Labor Statistics website: http://www.bls.gov/cew/cewfaq.htm
} 


\subsection{Instrumental Variables: The Political Roots of Health Insurance Benefit Mandates}

Most researchers studying the effects of mandates have used empirical strategies that assume mandates are passed randomly. Usually, researchers put mandates as a right-hand-side variable in an OLS or fixed effects regression and either ignore the endogeneity problem or argue that it is not important in their particular case. But mandates are passed by state legislatures, the outcome of a political process - a political process that can affect many health care and labor market outcomes besides mandates.

Webber and Bailey (2014) model the political process that gives rise to health insurance benefit mandates. They consider whether the passage of mandates is driven more by political parties and ideology, differing state institutions, producer interest groups, or greater need from consumers and patients. They run fixed effects regressions with state-level data from 2000 to 2010 and find that producer interest groups are the main reason some states pass more mandates than others, whereas political parties, the insurance status of patients, and state institutions such as mandate review boards do not significantly affect the number of mandates. In particular, states with a higher number of doctors per capita pass more mandates, and states with greater political contributions by insurers pass fewer mandates. Doctors benefit from mandates because health insurance increases the demand for their services. ${ }^{10}$ Insurers, by contrast, would prefer to have the freedom to design their own plans as they see fit. Webber and Bailey find the relationship between doctors per capita and mandates to be particularly strong — one additional doctor per 1,000 individuals (the difference between a state with few doctors like Idaho or Mississippi and an average state like Louisiana or Virginia) leads a state to have 10 additional mandates.

\footnotetext{
${ }^{10}$ The literature has found robust evidence ex-post moral hazard in health insurance (that is, more generous health insurance coverage means higher health spending); see, for instance, the Aron-Dine, Einav, and Finkelstein (2013) discussion of the RAND health insurance experiment.
} 
We use these variables, doctors per capita and political contributions by insurers, as instruments for mandates. We use the same data sources for these variables as were used by Webber and Bailey (2014). Data on physicians per capita come from the US Department of Health and Human Services' Area Resource File. These data are available on the state level from 1995 to 2011, with the exception of 2009. Data on political contributions come from the National Institute on Money in State Politics. These data are available back to 1996, although there is missing data for some states, especially in early years and in odd (nonelection) years. ${ }^{11}$

\subsection{Empirical Strategy: Panel Instrumental Variables}

We have a panel of annual, state-level data on the number of health insurance benefit mandates in effect and the number of employees at firms of various sizes from 1996 to 2010 . We begin by running naïve fixed effects regressions of mandates on employment of the following form:

$$
\text { Employmentst }_{\text {st }}=\text { Mandatesst }+\tau_{\mathrm{t}}+\theta_{\mathrm{s}}+\varepsilon_{\mathrm{st}}
$$

where Employmentst is total employment at firms in a specific size range in each state and year (we run separate regressions to determine how mandates affect employment at firms of various sizes), Mandates st is the number of health insurance benefit mandates in effect in that state and year, $\tau_{t}$ represents year dummies, $\theta_{s}$ represents state dummies, and $\varepsilon_{s t}$ is the error term.

But for this approach to produce an unbiased estimate of the effect of mandates on employment, the decision to pass mandates must be uncorrelated with employment changes. In reality, it may be the case that a trend or expectation of increasing employment could lead to more mandates being passed because of the perception that firms could afford the cost; this would bias estimates of the effect of mandates on employment upward.

\footnotetext{
${ }^{11}$ The data are publically available at www.followthemoney.org.
} 
To overcome the endogeneity problem and clearly identify the causal effect of mandates on employment and firm size, we developed instruments for mandates using doctors per capita and political contributions by insurers, variables that were previously determined to affect the passage of mandates (Webber and Bailey 2014). Our first stage equation is as follows: ${ }^{12}$

$$
\text { Mandatesst }=\text { Doctorsst }_{\text {s }}+\text { InsurerContributionsst }+\tau_{\mathrm{t}}+\theta_{\mathrm{s}}+\varepsilon_{\mathrm{st}}
$$

where $\tau_{t}$ represents year dummies, $\theta_{s}$ represents state dummies, and $\varepsilon_{s t}$ is the error term.

The second stage of our instrumental variables regression is

$$
\text { Employment }_{\mathrm{fst}}=\text { Mandates }_{\text {st }}+\tau_{\mathrm{t}}+\theta_{\mathrm{s}}+\varepsilon_{\mathrm{st}}
$$

where Employment fst $_{\text {is }}$ total employment at firms in a specific size range in each state and year (we run separate regressions to determine how mandates affect employment at firms of various sizes), is the first-stage equation's estimate of number of health insurance benefit mandates in effect in that state and year, $\tau_{t}$ represents year dummies, $\theta_{s}$ represents state dummies, and $\varepsilon_{s t}$ is the error term.

In addition to studying the effect of mandates on total employment at firms of various sizes, we study the effect of mandates on the total number of firms of various sizes. These regressions take the same form as the employment regressions, only with the standardized number of firms as a dependent variable. We use the natural log of the number of firms, while using the untransformed levels of employment, for two reasons. First is skewness: our summary statistics in table 1 show that the total number of employees in a state is remarkably consistent across firm sizes, while the total number of firms is much greater at smaller sizes. Second is to make consistent interpretation easier: a state gaining 15 small firms is very different from a state gaining 15 large firms.

\footnotetext{
${ }^{12}$ See the appendix for the first-stage instrumental variables results. Our instruments pass the $F$-test for instrument strength $(F=144.4)$ and Hansen's $J$ test for overidentification $(J=1.87)$.
} 


\section{Results}

\subsection{Effect on Employment}

Table 2 shows our main results for the effect of mandates on employment at firms of various sizes. Our first column shows the results of an OLS regression of mandates on employment, with no controls. It demonstrates that the simple correlation between mandates and the number of firms is positive and statistically significant for firms of all sizes. The magnitudes shown suggest that each mandate is associated with thousands of additional employees. Our second column adds state fixed effects and controls to the regression. Once the controls are taken into account, the estimated effect of mandates becomes much smaller and statistically insignificant for firms of all sizes, though most point estimates remain positive. Although the naïve OLS results could be used to argue that mandates actually encourage employment, the fixed effects results with year dummies reveal that the OLS results were biased by the omission of key variables.

The final column of table 2 shows the results of the instrumental variable (IV) regression, which accounts for the reasons mandates are passed. The IV estimates largely turn negative, suggesting that each mandate may reduce employment by hundreds of workers per state in most firm-size ranges. However, the IV results are imprecisely estimated, and we cannot reject the hypothesis that mandates have no effect on employment.

\subsection{Effect on Firms}

Table 3 shows our main estimates of mandates' effect of on firm size using regressions of the same form as before, but with the natural log of the number of establishments in each size range as the dependent variable instead of total employment at establishments in each size range. Our first column shows the results of an OLS regression of mandates on firm size, with no controls. It demonstrates that the simple correlation between mandates and the number of firms is positive 
and statistically significant for all firm sizes. This could imply that states with more firms are more likely to pass mandates or that mandates lead to more firms or that, in a spurious correlation, the number of mandates and firms have both grown over time, even though there is no causal relationship between them. Our second column shows the results of a fixed effects regression that controls for year dummies. We report no statistically significant effects in this column, and the magnitudes become much smaller and mostly negative.

The final column shows our instrumental variables results. Once we take into account the endogenous passage of mandates (as well as state and year fixed effects), we find statistically significant negative effects of mandates on the number of small firms with 5-9, 10-19, 20-49, and 50-99 workers. We also find negative, statistically insignificant effects on the number of very small (fewer than 5 workers) and medium-sized (100-249, 249-499, 500-999 workers) firms, but a positive and statistically significant effect on number of the largest firms $(1000+$ workers).

We use the log number of firms as the dependent variable, so the IV coefficient of -0.010 for firms with 5-9 employees should be interpreted as one additional mandate leading to a $1 \%$ reduction in the number of firms with 5-9 workers. This implies a loss of 272 firms with 5-9 workers in an average state. This loss is counteracted by a statistically significant $4.3 \%$ increase in the number of very large establishments (implying a gain of 5 establishments with 1,000 or more workers per mandate in an average state).

\subsection{Robustness}

There are barriers to interpreting our results as causal.

First, mandates are heterogeneous. Certain mandates apply only to small groups (such as including partners in a civil union on family plans) or require insurers to cover inexpensive 
treatments; others are mandates for costly treatments used by many people (such as dentistry). We estimate the effect of the average mandate on employment and the number of firms of various sizes, but the true effect of any given mandate may differ greatly from our estimates. A mandate that is more costly than average is likely to prompt a greater response from firms.

Second, whereas the QCEW data we use for employment and the number of firms of various sizes are built from rich, establishment-level data, the public version of the data we were able to access is aggregated to nine firm-size bins at the state-year level. This means that we can observe that mandates seem to reduce the number of firms with 50-99 employees, but we cannot say whether this effect holds equally for all firms in this category or whether our result is being driven by firms with 50-59 or 90-99 workers. Furthermore, the public QCEW data does not contain information gleaned from following specific firms over time. This means we cannot say the mechanism by which firms with 50-99 workers are disappearing. They could be closing entirely or shrinking to fewer than 50 workers or growing to more than 99 workers or any combination of the above. The quality of our data limits what we are able to say with confidence.

\section{Discussion}

Our instrumental variables estimation finds weak (i.e., not statistically significant) evidence that mandates decrease overall employment at small- and medium-sized firms. We find stronger evidence that mandates reduce the overall number of small firms (with 5 to 99 workers), and increase the number of large firms (with 1,000 or more workers). This is consistent with the idea that mandates are costly for the firms they apply to but that these costs can be escaped by selfinsuring under ERISA, which is much easier for large firms. Mandates appear to push firms toward the sizes that best enable them to escape the regulation. 
How is it possible for mandates to reduce the number of firms without reducing employment? Our results suggest that employment is being pushed toward larger firms. This is clearly occurring across firm-size bins: we find that mandates lead toward a statistically significant increase in the number of large (1,000-plus workers) firms in a state.

Though our data do not allow us to observe the exact size of firms, our results also suggest that mandates result in larger firms within each size category. We observe that mandates lead to fewer firms with 50-99 workers but do not cause a (statistically significant) decrease in total employment at firms with 50-99 workers. These findings can be reconciled if we are losing many firms with 50-60 workers while gaining some firms with 90-99 workers.

In one sense, our results are similar to those in the literature on group-specific health insurance benefit mandates. Lahey (2012) and Bailey (2014) find that when a mandate meant to benefit a group causes an increase in the cost of employing that group (for instance, an infertility treatment mandate and 28-to-42-year-old women), the mandate can decrease employment among that group without decreasing employment overall. In this study, we find that mandates change the distribution of employment by firm size without decreasing employment overall.

Suppose we are correct that the growing prevalence of health insurance benefit mandates, together with the ERISA self-insurance loophole that larger firms can more easily take advantage of, has led to the growth of large firms at the expense of small ones. Is this truly a problem? We argue that it is.

First, self-insurance is a costly way to escape mandates. Individuals and firms buy insurance for a reason - they value how it protects them from risk. Self-insuring means accepting the risk that some workers will get very sick all at once, requiring you to make much higher than expected payments for their claims. For truly large firms, this risk is very small. But for medium- 
sized firms, with say 100 workers, self-insuring still means accepting substantial risk; risk that firms would prefer to insure against if mandates did not make premiums too expensive.

Second, regulations that favor large firms over small ones contribute to a general decrease in economic dynamism. Economic dynamism - the birth and death of firms that embodies creative destruction — has been declining in the United States since the early 1980s (Decker et al. 2014). Recent work has found that this creative destruction, in particular entry by small, new firms, is crucial for job growth (Haltiwanger, Jarmin, and Miranda 2013), productivity (Syverson [2011] and Garicano, Lelarge and Van Reenan [2012] note the particular role of cost-increasing regulations in reducing productivity) and overall economic growth (Aghion 2013). The incredible importance of economic dynamism suggests that policymakers should be cautious about creating cost-increasing regulations and loopholes, such as health insurance benefit mandates with the ERISA self-insurance exemption, which fall disproportionally on small firms.

\section{Conclusion}

We find that health insurance benefit mandates, laws which increase the cost of providing health insurance, do not lead to statistically significant decreases in employment. However, these laws do lead to distortions in firm-size distribution. Because large firms can much more easily selfinsure, exempting their health insurance plans from state-level mandate regulations provides a competitive advantage for large firms. This distortion in firm size may lead to reduced dynamism and productivity growth. The use of self-insurance to escape mandates also means that firms take on risk that they would otherwise prefer to insure away. 


\section{References}

Aghion, Philippe, Ufuk Akcigit, and Peter Howitt. 2013. "What Do We Learn From Schumpeterian Growth Theory?" Working paper, National Bureau of Economic Research, Cambridge, MA. http://www.nber.org/papers/w18824.

Area Health Resources Files (AHRF). 2013-2014. US Department of Health and Human Services, Health Resources and Services Administration, Bureau of Health Workforce, Rockville, MD. http://ahrf.hrsa.gov/index.htm

Aron-Dine, Aviva, Liran Einav, and Amy Finkelstein 2013. “The RAND Health Insurance Experiment, Three Decades Later.” Journal of Economic Perspectives 27 (1): 197-222. http://www.economics.mit.edu/files/8400

Bailey, James. 2013. "The Effect of Health Insurance Benefit Mandates on Premiums.” Eastern Economic Journal 40 (1): 119-27. http://www.palgravejournals.com/eej/journal/v40/n1/full/eej201316a.html. . 2014. "Who Pays the High Health Costs of Older Workers? Evidence from Prostate Cancer Screening Mandates.” Applied Economics 46 (32): 3931-41. http://www.tandfonline.com/doi/abs/10.1080/00036846.2014.948673\#preview.

Bhattacharya, Jay, and William Vogt. 2000. "Could We Tell If Health Insurance Benefit Mandates Cause Unemployment? A Note on the Literature.” Working paper, University of Chicago Stigler Center, IL. www.chicagobooth.edu/assests/stigler/167.pdf.

Cutler, David, and Brigitte Madrian. 1998. "Labor Market Responses to Rising Health Insurance Costs: Evidence on Hours Worked.” The RAND Journal of Economics 29 (3): 509-30. 
Decker, Ryan, John Haltiwanger, Ron Jarmin, and Javier Miranda. 2014. "The Role of Entrepreneurship in US Job Creation and Economic Dynamism.” Journal of Economic Perspectives 28 (3): 3-24.

Feldman, Roger. 1993. "Who Pays for Mandated Health Insurance Benefits?” Journal of Health Economics 12 (3): 341-48. http://www.sciencedirect.com/science/article/pii/0167629693900168.

Fronstin, Paul. 2012. "Self-Insured Health Plans: State Variation and Recent Trends by Firm Size.” Technical report, Employee Benefit Research Institute, Washington, DC. http://www.ebri.org/publications/notes/index.cfm?fa=notesDisp\&content_id=5131.

Garicano, Luis, Claire Lelarge, and John Van Reenen. 2012. "Firm Size Distortions and the Productivity Distribution: Evidence from France.” Working paper, National Bureau for Economic Research, Cambridge, MA. http://www.nber.org/papers/w18841.

Glied, Sherry, Jeanne M. Lambrew, and Sarah Little. 2003. "The Growing Share of Uninsured Workers Employed by Large Firms.” Technical report, The Commonwealth Fund, New York. http://www.commonwealthfund.org/ /media/files/publications/fundreport/2003/oct/the-growing-share-of-uninsured-workers-employed-by-largefirms/glied_largefirms_672-pdf.pdf.

Gohmann, Stephan F., and Myra McCrickard. 2009. "The Effect of State Mandates on Health Insurance Premiums.” The Journal of Private Enterprise 24 (2): 59-73. http://journal.apee.org/index.php? title=Spring2009_5.

Gruber, Jonathan. 1994a. "The Incidence of Mandated Maternity Benefits." The American Economic Review 84 (3): 622-41. http://www.jstor.org/stable/2118071. 
1994b. "State-Mandated Benefits and Employer-Provided Health Insurance.” Journal of Public Economics 55 (3): 433-64.

http://www.sciencedirect.com/science/article/pii/0047272793014072.

Haltiwanger, John, Ron Jarmin, and Javier Miranda. 2013. "Who Creates Jobs? Small vs. Large vs. Young." Review of Economics and Statistics 95 (2): 347-61.

Jensen, Gail A., and Jon R. Gabel. 1992. "State Mandated Benefits and the Small Firm's Decision to Offer Insurance.” Journal of Regulatory Economics 4 (4): 379-404. http://link.springer.com/article/10.1007/BF00134929.

Kaestner, Robert, and Kosali Ilayperuma Simon. 2002. "Labor Market Consequences of State Health Insurance Regulation." Industrial and Labor Relations Review 56 (1): 136-59. http://www.jstor.org/stable/3270653.

Kapur, Kanika, Pinar Karaca-Mandic, Susan M. Gates, and Brent Fulton. 2012. “Do Small Group Health Insurance Regulations Influence Small Business Size?” Journal of Risk and Insurance 79 (1): 231-59. http://onlinelibrary.wiley.com/doi/10.1111/j.15396975.2011.01421.x/abstract.

Kowalski, Amanda E., William J. Congdon, and Mark H. Showalter. 2008. "State Health Insurance Regulations and the Price of High-Deductible Policies." Forum for Health Economics and Policy 11 (2): 1-26.

http://ideas.repec.org/a/bpj/fhecpo/v11y2008i2n8.html.

Lahey, Joanna N. 2012. “The Efficiency of a Group-Specific Mandated Benefit Revisited: the Effect of Infertility Mandates." Journal of Policy Analysis and Management 31 (1): 6392. http://dx.doi.org/10.1002/pam.20616. 
LaPierre, Tracey A., Christopher J. Conover, James W. Henderson, J. Allen Seward, and Beck A. Taylor. 2009. "Estimating the Impact of State Health Insurance Mandates on Premium Costs in the Individual Market.” Journal of Insurance Regulation 27 (3): 3-36.

Laudicina, Susan, Joan Gardner, and Kim Holland. 2011. "State Legislative Healthcare and Insurance Issues.” Technical report, Blue Cross and Blue Shield Association, Chicago, IL.

Lennon, Conor. 2015. “The Individual-Specific Impact of Employer-Sponsored Insurance: Evidence from the Affordable Care Act.” Technical report, University of Pittsburgh. http://www.conorjlennon.com/uploads/3/9/6/0/39604893/aca_summer_2015.pdf

Mathur, Aparna. 2010. "Health Insurance and Job Creation by the Self-Employed." Small Business Economics 35 (3): 299-317. http://link.springer.com/article/10.1007\%2Fs11187-008-9164-4\#.

Meer, Jonathan, and Jeremy West. 2011. "Identifying the Effects of Health Insurance Mandates on Small Business Employment and Pay.” Technical report, Texas A\&M, College Station. http://econweb.tamu.edu/jmeer/abs $\backslash \mathrm{s} \backslash$ do5(m)w $\backslash \mathrm{s} \backslash$ do5(m)andates.html.

Sloan, Frank, and Christopher Conover. 1998. "Effects of State Reforms on Health Insurance Coverage of Adults.” Inquiry 35 (3): 280-93. http://www.jstor.org/stable/29772768. Summers, Lawrence H. 1989. "Some Simple Economics of Mandated Benefits.” American Economic Review 79, 177-83. http://www.jstor.org/stable/1827753.

Syverson, Chad. 2011. "What Determines Productivity?" Journal of Economic Literature 49 (2): $326-65$. 
van der Goes, David N., Justin Wang, and Katharine C. Wolchik. 2011. "Effect of State Health Insurance Mandates on Employer-Provided Health Insurance.” Eastern Economic Journal 37 (4): 437-49. http://www.palgravejournals.com/eej/journal/v37/n4/abs/eej200950a.html.

Webber, Douglas, and James Bailey. 2014. "The Political Roots of Health Insurance Benefit Mandates.” Working paper, Mercatus Center, Arlington, VA. http://mercatus.org/publication/political-roots-health-insurance-benefit-mandates.

Wolaver, Amy, Timothy McBride, and Barbara Wolfe. 2003. "Mandating Insurance Offers for Low-Wage Workers: An Evaluation of Labor Market Effects." Journal of Health Politics, Policy, and Law 28 (5): 883-926. http://jhppl.dukejournals.org/content/28/5/883.abstract. 
Table 1. Summary Statistics: State-level Variables 1996-2010

\section{1a. Independent Variables}

\begin{tabular}{lccccc}
\hline Variable & Observations & Mean & Standard deviation & Minimum & Maximum \\
\hline Total mandates & 638 & 30.70 & 10.49 & 0.57 & 6.00001 \\
$\begin{array}{l}\text { Health political spending } \\
\text { Insurance political }\end{array}$ & 324 & 0.43 & 0.71 & 0.00002 & 0.39 \\
spending & 300 & 0.04 & 0.04 & 1.48 & 8.73 \\
Doctors per 1,000 people & 638 & 2.64 & 0.97 &
\end{tabular}

Note: All variables used are from state-level data from 1996-2010. Spending variables are measured in real 2011 dollars per state resident. Data on physicians per capita comes from the US Department of Health and Human Services' Area Resource File. Data on political contributions come from the National Institute on Money in State Politics. These data are available back to 1996, although there is missing data for some states, especially in early years and in odd (nonelection) years. Data on mandates are from Laudicina, Gardner and Holland (2011).

\section{1b. Employment by Firm Size (State-level)}

\begin{tabular}{|c|c|c|c|c|c|}
\hline Firm Size & Observations & Mean & $\begin{array}{l}\text { Standard } \\
\text { deviation }\end{array}$ & Minimum & Maximum \\
\hline$<5$ & 638 & 156,506 & 178,297 & 16,408 & $1,163,052$ \\
\hline $5-9$ & 638 & 176,020 & 178,305 & 19,726 & $1,006,772$ \\
\hline 10-19 & 638 & 234,964 & 239,531 & 25,394 & $1,412,658$ \\
\hline $20-49$ & 638 & 363,013 & 385,646 & 33,913 & $2,278,757$ \\
\hline 50-99 & 638 & 284,196 & 310,586 & 21,691 & $1,830,533$ \\
\hline $100-249$ & 638 & 355,522 & 383,637 & 20,820 & $2,158,862$ \\
\hline 250-499 & 638 & 203,077 & 218,189 & 0 & $1,188,226$ \\
\hline 500-999 & 638 & 147,883 & 159,183 & 0 & 815,361 \\
\hline $1,000+$ & 638 & 238,420 & 263,512 & 0 & $1,211,509$ \\
\hline All firms & 638 & $2,159,602$ & $2,295,256$ & 169,536 & $12,900,000$ \\
\hline
\end{tabular}


1c. Number of Establishments by Firm Size (State-level)

\begin{tabular}{|c|c|c|c|c|c|}
\hline Firm Size & Observations & Mean & $\begin{array}{l}\text { Standard } \\
\text { deviation }\end{array}$ & Minimum & Maximum \\
\hline$<5$ & 638 & 97,430 & 123,515 & 9,942 & 911,784 \\
\hline $5-9$ & 638 & 27,195 & 27,620 & 3,121 & 155,412 \\
\hline $10-19$ & 638 & 17,799 & 18,121 & 1,983 & 105,987 \\
\hline $20-49$ & 638 & 12,263 & 12,993 & 1,186 & 76,914 \\
\hline $50-99$ & 638 & 4,206 & 4,591 & 330 & 26,893 \\
\hline $100-249$ & 638 & 2,407 & 2,602 & 142 & 14,660 \\
\hline $250-499$ & 638 & 604 & 650 & 0 & 3,543 \\
\hline 500-999 & 638 & 221 & 239 & 0 & 1,237 \\
\hline $1,000+$ & 638 & 114 & 124 & 0 & 612 \\
\hline All firms & 638 & 162,239 & 188,675 & 17,101 & $1,267,235$ \\
\hline
\end{tabular}


Table 2. Effect of Mandates on Employment at Firms of Various Sizes

\begin{tabular}{|c|c|c|c|}
\hline Firm size & OLS & Fixed effects & $\begin{array}{l}\text { Instrumental variables } \\
\text { fixed effects }\end{array}$ \\
\hline \multirow{2}{*}{$<5$} & $6,503^{* *}$ & 207.6 & 1,650 \\
\hline & $(2,605)$ & (382.5) & $(1,318)$ \\
\hline \multirow{2}{*}{$5-9$} & $6,383 * *$ & -174.1 & -148.1 \\
\hline & $(2,450)$ & $(266.6)$ & $(554.5)$ \\
\hline \multirow{2}{*}{$10-19$} & $8,847^{* *}$ & 18.17 & 6.84 \\
\hline & $(3,363)$ & (409.5) & (795.5) \\
\hline \multirow{2}{*}{$20-49$} & $14,208 * *$ & 660.8 & -694 \\
\hline & $(5,469)$ & (780.4) & $(1,566)$ \\
\hline \multirow{2}{*}{ 50-99 } & $11,185^{* *}$ & 116.7 & -2050 \\
\hline & $(4,387)$ & $(556.7)$ & $(1,440)$ \\
\hline \multirow{2}{*}{$100-249$} & $13,631 * *$ & 851.6 & -361.7 \\
\hline & $(5,260)$ & $(554.4)$ & $(1,807)$ \\
\hline \multirow{2}{*}{$250-499$} & $7,259 * *$ & 343.5 & $-1,256$ \\
\hline & $(2,992)$ & (414.1) & $(1,652)$ \\
\hline \multirow{2}{*}{ 500-999 } & $4,802 * *$ & 349.1 & -611.8 \\
\hline & $(2,135)$ & $(600)$ & $(1,343)$ \\
\hline \multirow{2}{*}{$1,000+$} & $7,554^{* *}$ & 1,460 & 2,767 \\
\hline & $(3,180)$ & $(991.5)$ & $(2,543)$ \\
\hline Year dummies & No & Yes & Yes \\
\hline State dummies & No & Yes & Yes \\
\hline Observations & 620 & 620 & 652 \\
\hline
\end{tabular}


Table 3. Effect of Mandates on the Number of Firms of Various Sizes

\begin{tabular}{|c|c|c|c|}
\hline Firm size & OLS & Fixed effects & $\begin{array}{c}\text { Instrumental variables } \\
\text { fixed effects }\end{array}$ \\
\hline \multirow{2}{*}{$<5$} & $0.039 * * *$ & -0.002 & -0.001 \\
\hline & $(0.010)$ & $(0.002)$ & $(0.006)$ \\
\hline \multirow{2}{*}{$5-9$} & $0.034 * * *$ & -0.001 & $-0.010 * * *$ \\
\hline & $(0.009)$ & $(0.001)$ & $(0.003)$ \\
\hline \multirow{2}{*}{ 10-19 } & $0.036 * * *$ & -0.001 & $-0.013^{* * *}$ \\
\hline & $(0.009)$ & $(0.001)$ & $(0.004)$ \\
\hline \multirow{2}{*}{$20-49$} & $0.038 * * *$ & 0.000 & $-0.008^{* *}$ \\
\hline & $(0.010)$ & $(0.001)$ & $(0.004)$ \\
\hline \multirow{2}{*}{ 50-99 } & $0.039 * * *$ & -0.003 & $-0.023 * * *$ \\
\hline & $(0.010)$ & $(0.002)$ & $(0.006)$ \\
\hline \multirow{2}{*}{$100-249$} & $0.040 * * *$ & 0.000 & -0.005 \\
\hline & $(0.010)$ & $(0.001)$ & $(0.004)$ \\
\hline \multirow{2}{*}{$250-499$} & $0.038 * * *$ & -0.005 & -0.005 \\
\hline & $(0.011)$ & $(0.004)$ & $(0.003)$ \\
\hline \multirow{2}{*}{ 500-999 } & $0.033 * * *$ & -0.003 & -0.012 \\
\hline & $(0.011)$ & $(0.003)$ & $(0.010)$ \\
\hline \multirow{2}{*}{$1,000+$} & $0.036 * * *$ & 0.004 & $0.043^{* * *}$ \\
\hline & $(0.011)$ & $(0.004)$ & $(0.013)$ \\
\hline Year dummies & No & Yes & Yes \\
\hline State dummies & No & Yes & Yes \\
\hline Observations & 620 & 620 & 652 \\
\hline
\end{tabular}

errors are in parentheses; the standard errors for the OLS and fixed effects regressions are robust and clustered at the state level. Fixed effects and IV regressions control for state population. The instrumental variables column shows the second stage of IV regressions; the first stage uses doctors per capita and political contributions by insurers as instruments for mandates.

\section{Appendix}

Table A.1. Details of Instrumental Variable Estimation-First Stage Results

\begin{tabular}{lc}
\hline & Instrumenting for total mandates \\
\hline Doctors per capita & $5.242^{* * *}$ \\
& $(1.196)$ \\
Political contributions by insurers & .0388 \\
Observations & $(.0849)$ \\
F-statistic & 652 \\
\hline Note: Coefficients are omitted for controls (year fixed effects, state fixed effects, state population). Standard errors \\
are given in parentheses; $* * * \mathrm{p}<0.01, * * \mathrm{p}<0.05, * \mathrm{p}<0.1$.
\end{tabular}

